\author{
ANTONIO PIETRO GARONNA ${ }^{1}$ - UMBERTO BERNARDO ${ }^{2}$ \\ LIBERATA GUALTIERI ${ }^{2}$ - STEFANIA LAUDONIA ${ }^{1}$ - FRANCESCO NUGNES ${ }^{2}$
}

\title{
THE PRESENT PEST STATUS OF EUCALYPTUS SAP-SUCKERS AND GALL WASPS IN CAMPANIA (ITALY) $\left({ }^{1}\right)$
}

\begin{abstract}
$\left(^{+}\right)$Università degli Studi di Napoli Federico II: Dipartimento di Agraria, Sezione di Biologia e Protezione dei sistemi agricoli e forestali (BiPAF), Via Università 100, 80055, Portici, Italy; E-mail: garonna@unina.it $\left({ }^{2}\right)$ CNR: Istituto per la Protezione Sostenibile delle Piante (IPSP), Via Università 133, 80055, Portici, Italy.
\end{abstract}

\begin{abstract}
Garonna A.P., Bernardo U., Gualtieri L., Laudonia S., Nugnes F. - The present pest status of Eucalyptus sap-suckers and gall wasps in Campania

Sap-suckers and gall wasps may be a severe phytosanitary problem for several Eucalyptus species, particularly for the red gum E. camaldulensis, the most widely cultivated Australian native tree species worldwide. This paper reviewed the harmfulness of some of these invasive pests established in Campania, and provides new information about their pest status.
\end{abstract}

KeY Words: Red gum, bronze bug, Aphalaridae, Eulophidae, biological control.

Sap-suckers can be a serious phytosanitary problem of Eucalyptus species worldwide. During the last 30 years 4 allochthonous species of Aphalaridae (Psylloidea) and one species of Thaumastocoridae living on Myrtaceae and infesting mainly Eucalyptus spp. have been accidentally introduced in Italy. Chronologically listed the involved psyllids are, Ctenarytaina eucalypti (Maskell), Ctenarytaina spatulata Taylor, Blastopsylla occidentalis Taylor, and Glycaspis brimblecombei Moore, with the last two species widespread in Campania. In addition, the bronze bug, Thaumastocoris peregrinus Carpintero \& Dellapé, must be added as the last established pest in the region (LAUDONIA and SASSO, 2012).

Among the psyllids, G. brimblecombei, which is commonly known as red gum lerp psyllid, is easily recognized by the nymphal stages protected by the conical crystalline white coverings (lerps) of secreted wax mixed with excreted honeydew (Fig. I, 1). The speed of its world invasion has few precedents. Native to Australia, the species is today considered a cosmopolitan pest and is recorded in 24 countries (EPPO, 2017). The first Italian record dated back to 2010, when huge populations were found spread over a large territory in Campania (LAUDONIA and GARONNA, 2010). The preferred host of G. brimblecombei is $E$. camaldulensis, largely distributed in the Mediterranean basin, where it is used as hardwood species in forestry and as ornamental species in urban greenery. The lerp psyllid (Fig. I, 2) became in few years a harmful pest detrimental to red gum trees with strong economic impact also involving the beekeeping sector. The heavy environmental and economic impact of chemical control (e.g. high cost and low effectiveness of pesticide applications due to overlap-

\footnotetext{
${ }^{1}$ Original scientific contribution presented and discussed at the National Symposium on "Health status of Eucalyptus plantations in Italy", Oristano (Centro Congressi Hotel Anfora, Tramatza) - Italy, March 24-25, 2017.
}

ping generations) led to investigations on natural control realized by indigenous entomophagous species. Biological observations highlighted the limited role of generalist predators like anthocorids and ladybirds (Coccinella septempunctata, Adalia spp., Oenopia sp., Scymnus sp., Chilocorus bipustulatus), chrysopids (Chrysopa sp.), hoverflies larvae and predatory wasps (Vespula sp.) (LAUDONIA and GARONNA, 2010). Interestingly the wasps fed on honeydew and also on nymphal stages of the psyllid raising the lerp coverings. Among all recorded predatory species Anthocoris nemoralis Fabricius (Hemiptera: Anthocoridae) (Fig. I, 3), resulted the most efficient, preying adults and all preimaginal stages (GARONNA et al., 2011).

The accidental introduction of the main parasitic species of the lerp psyllid in the Mediterranean basin, Psyllaephagus bliteus Riek (Hymenoptera: Encyrtidae), changed the biological control scenario. The encyrtid, already employed with success in biological control (BC) programmes in California, Brazil, Mexico e Chile, was first recorded in Campania during fall 2012 (Fig. I, 4). Nowadays the parasitoid controls the lerp psyllid in large part of the Italian territory. A recently published study about the host-parasitoid interaction showed that $P$. bliteus, even with low-density population of its own host, is strictly influenced by environmental factors (LAUDONIA et al., 2013). In fact, population dynamics of host and parasitoid is affected by the seasonal trend of the climate, mainly during summer where high temperatures and limited rainfall can affect both species. Predictive modelling applied to this system highlighted a potential reduction of G. brimblecombei population density up to $64 \%$ due to $P$. bliteus activity (MARGIOTTA et al., 2017). In this scenario the pest species will persist in the environment reaching sometimes harmful densities detrimental to E. camaldulensis.

$B$. occidentalis, a species with negligible phytosanitary importance in Campania, preferably infests the apical trait of twigs. The eggs of the species can be found on shoots, leaf axils, small branches and young leaves. The pre- 


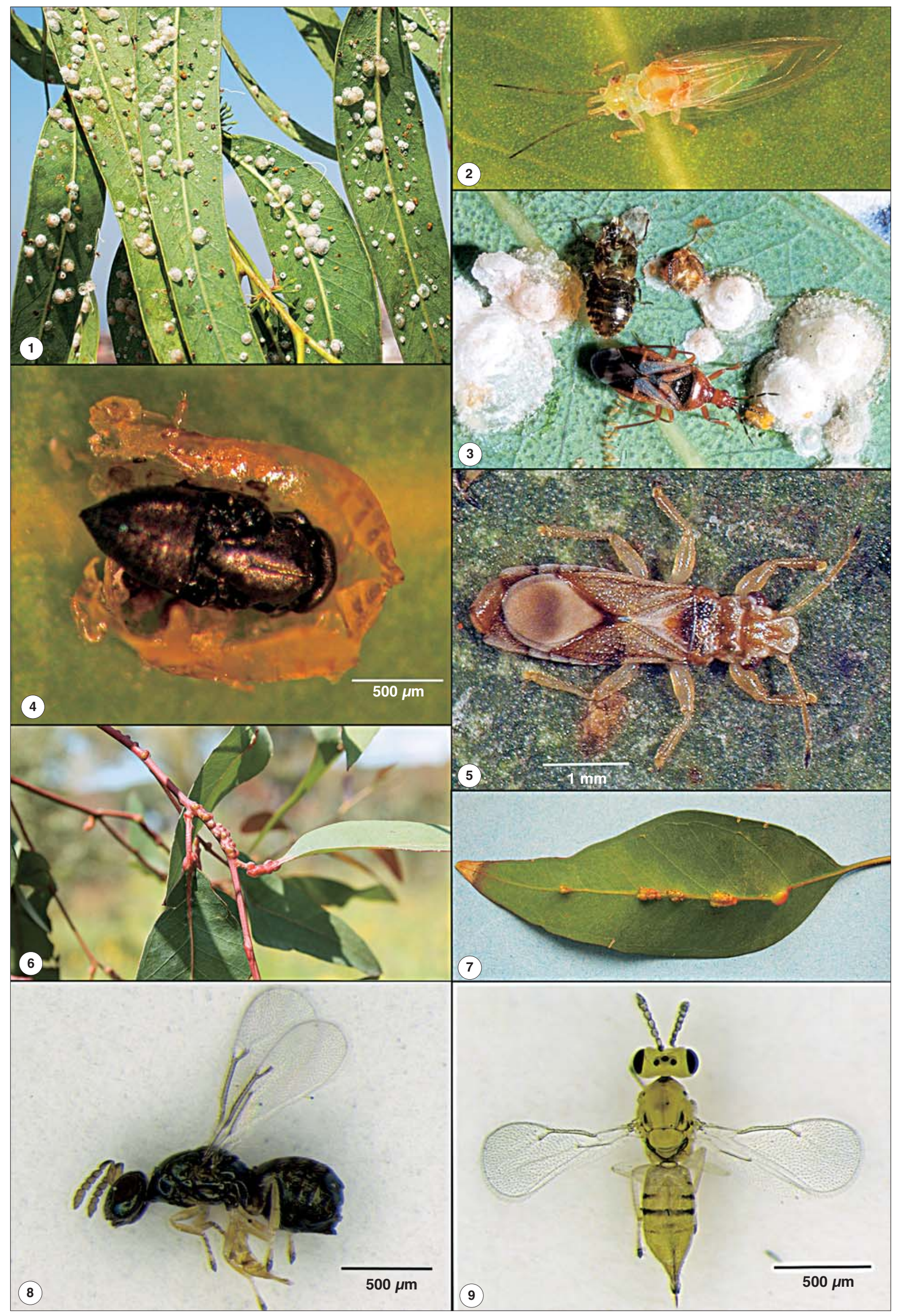

Fig. I - 1, colony of Glycaspis brimblecombei; 2, adult of lerp psyllid; 3, Anthocoris nemoralis feeding on lerp psyllids; 4, pupa of Psyllaephagus bliteus; 5, adult of Thaumastocoris peregrinus; 6, Leptocybe invasa galls on stem and petiole of Eucalyptus sp.; 7, L. invasa galls on eucalypt leaf main nerve; 8, female of L. invasa; 9, female of Quadrastichus mendeli. 
imaginal stages are covered only by fluffy whitish wax and produce powdery globules of honeydew. Since its discovery in Campania (LAUDONIA, 2006) this psyllid has always been recorded at low density throughout the region. Scarce natural control is carried out by the same predatory species attacking the lerp psyllid. Up to now no parasitoid of $B$. occidentalis has been collected.

The bronze bug, T. peregrinus (Fig. I, 5), is native to Australia, where it feeds on a wide range of Eucalyptus species (CARPintero and Dellapé, 2006; NoACK et al., 2011; Soliman et al., 2012; Mutitu et al., 2013). It is also an invasive species that has spread to South Africa and Réunion (JACOBS and NeSER, 2005; Streito et al., 2016), South and Nord America (NoACK and Coviella, 2006; WiLCKEN et al., 2010; MARTíNEZ and BIANCHI, 2010; IDE et al., 2011; JiMÉNEZ Quiroz et al., 2016; ARAKELIAN, 2016) and New Zealand (SOPOW and GEORGE, 2012). T. peregrinus, to date the only species belonging to thaumastocorids in the Fauna of Europe, has been reported for the first time for the Mediterranean basin in Italy (LAUDONIA and SASSO, 2012). Thereafter, the bronze bug has established in Portugal (GARCIA et al., 2013), Spain (VIVAs et al., 2015), Israel (Novoselsky and Freiberg, 2016) and Albania (VAN Der Heyden, 2017). T. peregrinus causes leaf discoloration (bronzing, reddening, yellowing), early senescence and stunted growth. Heavy infestations can lead to severe defoliation, branch dieback, and in some cases, tree mortality (LAUDONIA and SASSO, 2012). The adults are light brown with a flattened body (2-3.5 mm). Eggs are typical dark, oval (0.5 mm long - $0.2 \mathrm{~mm}$ wide) with a sculptured chorion often laid in clusters on leaves and twigs. The eggs, the 5 pre-imaginal stages and the adults can be present on the same leaf. The life cycle is rather short, approximately 35 days in laboratory conditions $\left(20\right.$ days at $\left.17-20^{\circ} \mathrm{C}\right)$, and in the same condition, a female can lay approximately 60 eggs during its lifespan. However, it is difficult to study the timing and phenology of population fluctuations in the field (NoACK and Rose, 2007; JACOBS and NeSER, 2005; BOUVET and VACCARO, 2007). Data collected in Italy confirm that $T$. peregrinus has not any diapause period remaining active during all seasons, even though sometimes in very low numbers (NADEL et al., 2015; LAUDONIA et al., 2016).

After a first steady trend during January-April 2015, at very low density $(<0.05$ specimens/leaf $)$, a significant increase of the bronze bug population has been recorded in Campania from April to October (Fig. II). In particular, an exponential growth from the end of August of the same year has been observed (LAUDONIA et al., 2016). Finally, it can be asserted that, at our latitudes and in field, the species is limited by unfavourable temperatures below $11^{\circ} \mathrm{C}$ and above $30{ }^{\circ} \mathrm{C}$ (LAUDONIA et al., 2016).

In some countries the chemical control option for $T$. peregrinus is Imidacloprid, with systemic trunk injection also. Chemical control is not effective and at the same time unfriendly to the environment; moreover, it is both time consuming and costly (WILCKEN et al., 2010; ZANUNCIO et al., 2010). In Italy, like in other areas of the world, there are no registered chemical options against $T$. peregrinus. Until now, no European indigenous enemy has been reported associated to the Bronze bug. In the native area, the most effective natural enemy is the egg parasitoid Cleruchoides noackae Lin and Huber (Hymenoptera: Mymaridae) (LiN et al., 2007). Host specificity tests established that $C$. noackae is able to parasitize other species of Thaumastocoridae, but

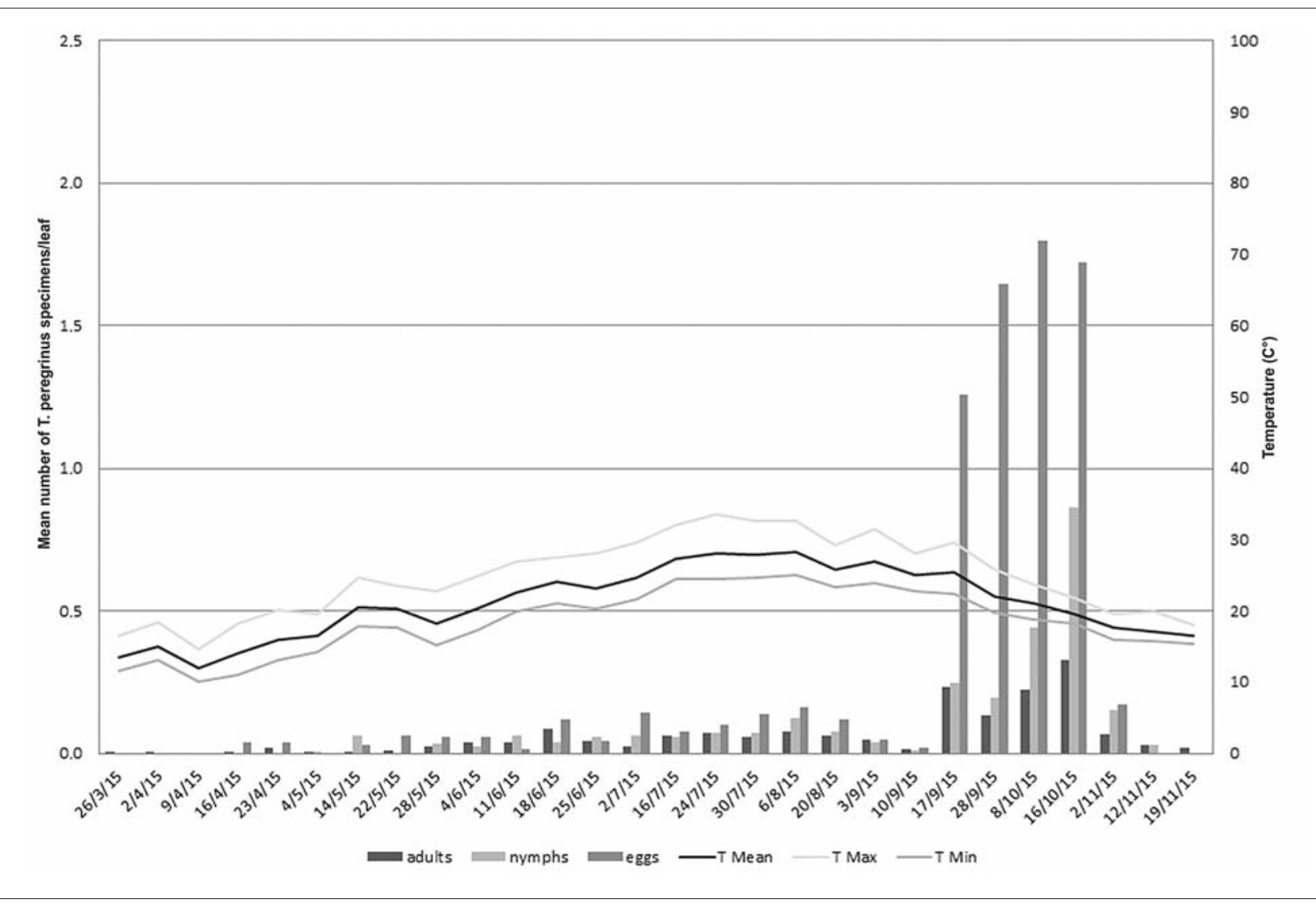

Fig. II - Mean values of T. peregrinus specimens per sampled leaf in Italy related to temperature $\left({ }^{\circ} \mathrm{C}\right)$. 
no attacks against potential hosts outside of this family have been recorded. This specificity allowed the release of $C$. noackae as a biological control agent of the Bronze bug in Chile, Brazil and South Africa (NYEKO, 2011; BARBOSA et al., 2017). So far, data on effectiveness of these realized biological control programs are not yet available in the literature.

The following two gall wasps (Hymenoptera: Eulophidae) in Campania may coexist without signs of interspecific competition since they occupy different ecological niches.

Ophelimus maskelli (Ashmead) has been the first eulophid gall-wasp recorded in Campania region during 2001 and misidentified as $O$. eucalypti (Gahan) (VIGgIanI and Nicotina, 2001) up to Protasov et al. (2007a). The wasp reproduces by thelytokous parthenogenesis and induces numerous small pimple-like, greenish-yellow to reddish, nearly round galls as the result of the oviposition and development of the larval stages (RAMAN and WITHERS, 2003; LAUDONIA and VigGianI, 2004). The galls are visible on both sides of the red gum tree leaves. The wasp attacks mainly the lower canopy developing three generations per year with a clear tendency to oviposit in developed, immature leaves. $O$. maskelli causes severe injury on $E$. camaldulensis determining dramatic leaf dieback and premature phylloptosis in few years both in urban and forest environments.

The harmfulness of this species, widespread in the Mediterranean basin, induced the organization of a classical biological control program on a large scale. Italy, too, was involved in this BC program. During 2006 the main parasitoid of the gall wasp, the eulophid Closterocerus chamaeleon (Girault), which was reared and distributed in Israel first (MENDEL et al., 2007), was introduced in Campania and in the southernmost regions of the country (SASSO et al., 2008; CALECA et al., 2011).

The highly efficient parasitoid species established in few weeks in all release sites and spread over a wide area in the same year, with recorded parasitization rates up to $60 \%$ (SASSO et al., 2008). The continuous and long-distance dispersal mechanisms typical of $C$. chameleon, which was assessed in Italy, enhanced its effectiveness as a biological control agent (CALECA et al., 2011). The success in the whole Mediterranean basin of this classical BC program realized against $O$. maskelli is one of the most powerful applications of this low impact control method. In about three years, populations of the harmful gall wasp have been significantly reduced by $C$. chamaeleon with positive impact for $E$. camaldulensis in all its growing areas (MENDEL et al., 2017). The introduction of a second parasitoid, belonging to the genus Stethinium (Chalcidoidea: Mymaridae) has been realized in the same year (2006) but without success (SASSO et al., 2008). The present status of $O$. maskelli on $E$. camaldulensis in Campania has been reduced to an occasional secondary pest.

A second species of eulophid gall wasp infesting $E$. camaldulensis was recorded in Campania in the same year of $O$. maskelli (2001) and considered as a new species belonging to the genus Aprostocetus (VIGGIANI et al., 2001). However, later the wasp was described as a new genus and species native to Australia and named Leptocybe invasa Fisher et La Salle (MENDEL et al., 2004). Rapid and harmful pest invasions are already widely-known, but L. invasa manifested an uncommon high spreading effectiveness and speed during its world invasion. Thanks to its high ecological plasticity, the blue-gum chalcid in 15 years has invaded the five continents spreading to about 40 countries and becoming a serious pest for eucalypt plantations in the world (NugNES et al., 2015; MENDEL et al., 2004).

L. invasa attacks tissues both of the stems and the leaf main nerve and petioles of new shoots where it lays eggs inducing the formation of typical bump-shaped galls (Fig. I, 6-7). The gall development eventually results in leaf-curling and premature aging of the leaves and severe attacks might cause death of juvenile shoots and leaves fall, resulting in stunted growth and tree weakening (MENDEL et al., 2004).

In addition to its ecological plasticity, the blue-gum chalcid has been facilitated in spreading by its particular reproductive modality. Rickettsia symbiont in fact is the causal agent of thelytokous parthenogenesis in L. invasa (Nugnes et al., 2015) allowing a few females (Fig. I, 8) to infest a new territory in a very short time.

Recent integrative characterization highlighted that the population of L. invasa and its own Rickettsia symbiont recovered in Campania share the same molecular sequences with other populations recovered all over the Mediterranean region and South America. This population has a female biased sex-ratio and is characterized by rare occurrences of males.

Since the first finding in Campania, L. invasa has built up dense populations and spread all over the region territory. This behaviour was clearly in contrast to the small populations found in the native country, where L. invasa is limited by the presence of indigenous natural enemies (KIM et al., 2008; Nugnes et al., 2016; MeNDEL et al., 2017).

In native and invaded countries, from $L$. invasa galls, were sporadically reared Megastigmus spp. (Torymidae), Aprostocetus sp. (Eulophidae: Tetrastichinae), Parallelaptera sp. (Mymaridae), and Telenomus sp. (Platygasteridae) (VIGGIANI et al., 2001b; ProtASOV et al., 2008; DOĞANLAR and HASSAN, 2010; VASTRAD et al., 2010; DOĞANLAR et al., 2013; SANGTONGPRAOW and CHARERNSOM, 2013) but their effectiveness in the control of bluegum chalcid has not been already ascertained. However, the most effective natural enemies resulted to be the Tetrastichinae wasps Selitrichodes krycery Kim et La Salle (KIm et al., 2008), S. neseri Kelly et La Salle (Kelly et al., 2012), and Quadrastichus mendeli Kim et La Salle (KIM et al., 2008) (Fig. I, 9).

Starting from 2007, Q. mendeli and S. krycery were released in Israel in BC program against blue-gum chalcid. Although $Q$. mendeli was never officially released in Italy, since 2013 it was unexpectedly collected for the first time in Campania and in following years also in neighbouring regions of Central and Southern Italy (NUGNES et al., 2016). In Campania, samplings carried out on L. invasa infested trees showed a parasitization rate by $Q$. mendeli ranging from $27.3 \%$ to $100 \%$.

Since its first finding in Campania, the activity of the parasitoid became stronger year after year and decisive for the containment of the blue-gum chalcid. L. invasa galls have almost completely disappeared, in several sampled places (NUGNES et al., 2016). Likely, the short life-cycle of $Q$. mendeli [usually 30 days from egg to adults (KIM et sal., 2008)] and its thelytokous reproduction, mediated by Rickettsia symbiont (GUALTIERI et al., 2017), have a synergistic effect on its effectiveness in the control of $L$. invasa.

In conclusion, field investigations carried out in recent years report that only few insect species can be considered real pests of Eucalyptus in Campania. While the impact of the gall-wasps has been strongly reduced by the spread of specific natural enemies, two sap-suckers, the lerp psyllid G. brimblecombei and the bronze bug T. peregrinus, are still 
able to develop harmful populations mainly in urban environment due to incomplete or lack of natural control. Further surveys can lead to a more exhaustive frame of the pest status of the bronze bug on Eucalyptus species, which may be essential to the development of control tools and strategies to reduce the harmfulness of this pest.

\section{REFERENCES}

Arakelian G., 2016 - Bronze bug (Thaumastocoris peregrinus). In: Pest bulletin of Los Angeles County Department of Agricultural Commissioner. Unpublished. Available at: https://doi.org/10.13140/rg.2.2.26693.65766

Arzone A., Alma A., 2000 - Eulofíde galligeno dell'Eucalipto in Italia. - Inf. Fitopatol., 50: 43-46.

Barbosa L.R., Rodrigues A.P., Da Silva Soler L., Vique Fernandes B., Monteiro De Castro E Castro B., WILCKEN C.F., ZANUNCIO J.C., 2017 - Establishment in the field of Cleruchoides noackae (Hymenoptera: Mymaridae), an exotic egg parasitoid of Thaumastocoris peregrinus (Hemiptera: Thaumastocoridae). - Fla. Entomol., 100: 372-374.

Bouvet J.P., VAcCARo N., 2007 - Nueva especie de chinche, Thaumastocoris peregrinus (Hemiptera: Thaumastocoridae) en plantaciones de eucalipto en el departamento Concordia, Entre Ríos, Argentina - In: XXII Jornadas Forestales de Entre Ríos, Concordia, Argentina: 1-2.

CABI, 2015 - Leptocybe invasa. In: Invasive species compendium. - CAB International, Wallingford, UK. [online] URL: http://www.cabi.org/isc/datasheet/108923

Caleca V., Lo Verde G., Maltese M., 2011 - First record in Italy of Psyllaephagus bliteus Riek (Hymenoptera: Encyrtidae) parasitoid of Glycaspis brimblecombei Moore (Hemiptera: Psyllidae). - Nat. Sicil., 35(3-4): 435444.

Caleca V., Lo Verde G., Rizzo M.C., Rizzo R., 2011 Dispersal rate and parasitism by Closterocerus chamaeleon (Girault) after its release in Sicily to control Ophelimus maskelli (Ashmead) (Hymenoptera, Eulophidae). - Biol. Control, 57: 66-73.

Carpintero D., Dellapé P., 2006 - A new species of Thaumastocoris Kirkaldy from Argentina (Heteroptera: Thaumastocoridae: Thaumastocorinae). - Zootaxa, 1228: 61-68.

Costanzi M., Malausa J.C., Cocquempot C., 2003 - Un nouveau psylle sur les Eucalyptus de la Riviera Ligure et de la Côte d'Azur. Premières observations de Ctenarytaina spatulata Taylor dans le Bassin Méditerranéen occidental. - Phytoma, 566: 48-51.

De Marzo L., 2007 - Reperimento del parassitoide Closterocerus chamaeleon (Girault) in Basilicata e Puglia (Hymenoptera Eulophidae). - Boll. Zool. Agr. Bach., 39: 231-237.

DoĞanlar M., Hassan E., 2010 - Review of Australian species of Megastigmus (Hymenoptera: Torymidae) associated with Eucalyptus, with descriptions of new species. - Aust. J. Basic. Appl. Sci., 4: 5059-5120.

DoĞanlar M., ZachÉ B., WilcKen C.F., 2013 - A new species of Megastigmus (Hymenoptera: Torymidae: Megastigminae) from Brazil. - Fla. Entomol., 96: 196199.

EPPO, 2017 - PQR - EPPO database on quarantine pests. [online] http://www.eppo.int

Garcia A., Figueiredo E., Valente C., Monserrat V.J., BRANCO M., 2013 - First record of Thaumastocoris peregrinus in Portugal and of the neotropical predator Hemerobius bolivari in Europe. - Bull. Insectology, 66(2): 251-256.

Garonna A.P., SASSO R., LAUdonia S., 2011 - Glycaspis brimblecombei (Hem.: Psyllidae), la psilla dal follicolo bianco ceroso, altra specie aliena dell'Eucalipto rosso in Italia. - Forest@, DOI: 10.3832/efor0654-008.

Gualtieri L., Nugnes F., Nappo A.G., Gebiola M., BERNARDO U., 2017 - Life inside a gall: closeness does not favour horizontal transmission of Rickettsia between a gall wasp and its parasitoid. - FEMS Microbiol. Ecol., 93(7): 1-7.

Ide S., Ruiz C., Sandoval A., Valenzuela J., 2011 Detección de Thaumastocoris peregrinus (Hemiptera: Thaumastocoridae) asociado a Eucalyptus spp. en Chile. - Bosque, 32: 309-313.

JACOBS D.H., NESER S., 2005 - Thaumastocoris australicus Kirkaldy (Heteroptera: Thaumastocoridae): a new insect arrival in South Africa, damaging to Eucalyptus trees. S. Afr. J. Sci., 101: 233-236.

Jiménez-Quiroz E., VAnegas-Rico JM., MoralesMartíneZ O., LOMELI-Flores JR., ROdRÍGUEZ-LEYVA E., 2016 - First record of the bronze bug, Thaumastocoris peregrinus Carpintero \& Dellapé 2006 (Hemiptera: Thaumastocoridae), in Mexico. - J. Agr. Urban Entomol., 32: 35-39.

Kelly J., La Salle J., Harney M., DitTrich-SchröDer G., Hurley B.P., 2012 - Selitrichodes neseri $n$. sp, a new parasitoid of the Eucalyptus gall wasp Leptocybe invasa Fisher \& La Salle (Hymenoptera: Eulophidae: Tetrastichinae). - Zootaxa, 3333: 50-57.

Kim I., Mendel Z., Protasov A., Blumberg D., 2008 Taxonomy, biology, and efficacy of two Australian parasitoids of the eucalyptus gall wasp, Leptocybe invasa Fisher \& La Salle (Hymenoptera: Eulophidae: Tetrastichinae). - Zootaxa, 1910: 1-20.

Laudonia S., 2005 - Catture di Ophelimus eucalypti (Gahan) (Hym.: Eulophidae) imenottero galligeno dell'Eucalyptus con trappole cromotropiche e prove di controllo. In: Atti del XX Congresso Nazionale Italiano di Entomologia, Assisi (PG) 13-18 giugno 2005: 295.

LaUdonia S., Garonna A.P., 2010 - The red gum lerp psyllid, Glycaspis brimblecombei, a new exotic pest of Eucalyptus camaldulensis in Italy. - Bull. Insectology, 63: 233-236.

LAUdONiA S., MARgiotTA M., D’Orsi M., 2016 - Fenologia $e$ distribuzione di Thaumastocoris peregrinus Carpintero \& Dellapè (Heteroptera: Thaumastocoridae) su Eucalyptus spp. in ambiente urbano. In: Atti del XXV Congresso Nazionale Italiano di Entomologia, Padova 20-24 giugno 2016: 305.

LAUdonia S., Margiotta M., SAsso R., 2013 - Seasonal occurrence and adaptation of the exotic Glycaspis brimblecombei Moore (Hemiptera: Aphalaridae) in Italy. - J. Nat. Hist., 48: 675-689.

LaUdonia S., SAsso R., 2012 - The bronze bug Thaumastocoris peregrinus: a new insect recorded in Italy, damaging to Eucalyptus trees. - Bull. Insectology, 65: 89-93

LaUdonia S., Viggiani G., 2004 - Descrizione degli stadi preimmaginali dell'Imenottero galligeno Ophelimus eucalypti (Gahan) (Hymenoptera: Eulophidae). - Boll. Lab. Ent. Agr. Filippo Silvestri, 59 (2003): 93-98

Laudonia S., Viggiani G., Sasso R., 2006 - Nuova introduzione in Italia. Parassitoide esotico in aiuto degli eucalipti. - L'Informatore Agrario, 63(40): 74.

Lin N.Q., Huber J.T., LA SAlle J., 2007 - The Australian 
genera of Mymaridae (Hymenoptera: Chalcidoidea). Zootaxa, 1596: 1-111.

Margiotta M., Bella S., Buffa F., Caleca V., Floris I.V., Giorno V., Lo Verde G., Rapisarda C., Sasso R., Suma P., Tortorici F., Laudonia S., 2017 - Modeling environmental influences in the Psyllaephagus bliteus (Hymenoptera: Encyrtidae)-Glycaspis brimblecombei (Hemiptera: Aphalaridae) parasitoid-host system. - J. Econ. Entomol., 110(2): 491-501.

Martínez G., Bianchi M., 2010 - Primer registro para Uruguay de la chinche del eucalipto, Thaumastocoris peregrinus Carpintero y Dellapé, 2006 (Heteroptera: Thaumastocoridae). - Agrociencia, 14: 15-18.

Mendel Z., Protasov A., Fisher N., La SAlle J., 2004 Taxonomy and biology of Leptocybe invasa gen. and $s p$. n. (Hymenoptera: Eulophidae), an invasive gall inducer on Eucalyptus. - Aust. J. Entomol., 43(2): 101-113.

Mendel Z., Protasov A., Blumberg D., Brand D., SAPhir N., MADAR Z., LA SALLE J. 2007 - Release and recovery of parasitoids of the Eucalyptus gall wasp Ophelimus maskelli in Israel. - Phytoparasitica, 35: 330-332.

Mendel Z., Protasov A., La Salle J., Blumberg D., Brand D., Branco M., 2017 - Classical biological control of two Eucalyptus gall wasps; main outcome and conclusions. - Biol. Control, 105: 66-78.

Mutitu E.K., Garnas J.R., Hurley B.P., Wingfield M.J., Harney M., Bush S.J., Slippers B., 2013 - Biology and rearing of Cleruchoides noackae (Hymenoptera: Mymaridae), an egg parasitoid for the biological control of Thaumastocoris peregrinus (Hemiptera: Thaumastocoridae). - J. Econ. Entomol., 106: 1979-1985.

NAdel R.L., Wingfield M.J., Scholes M.C., Garnas J.R., Lawson S.A., SLIPPers B., 2015 - Population dynamics of Thaumastocoris peregrinus in Eucalyptus plantations of South Africa. - J. Pest. Sci., 88: 97.

NoAck A.E., CAssis G., Rose H.A., 2011 - Systematic revision of Thaumastocoris Kirkaldy (Hemiptera: Heteroptera: Thaumastocoridae). - Zootaxa, 3121:1-60.

NoAck, A.E., Coviella, L.E. 2006 - Scientific Note: Thaumastocoris australicus Kirkaldy (Hemiptera Thaumastocoridae): First record of this invasive pest of Eucalyptus in the Americas. - Gen. Appl. Ent., 35: 13-14.

NoAck, A.E., Rose H.A, 2007 - Life-history of Thaumastocoris peregrinus and Thaumastocoris $s p$. in the laboratory with some observations on behaviour. - Gen. Appl. Ent., 36: 27-33.

Novoselsky T., Freidberg A., 2016 - First record of Thaumastocoris peregrinus (Hemiptera: Thaumastocoridae) in the Middle East, with biological notes on its relations with eucalyptus trees. - Isr. J. Entomol., 46: 43-55.

Nugnes F., Gebiola M., Monti M.M., Gualtieri L., Giorgini M., Wang J., Bernardo U., 2015 - Genetic diversity of the invasive gall wasp Leptocybe invasa (Hymenoptera: Eulophidae) and of its Rickettsia endosymbiont, and associated sex-ratio differences. PLoS ONE, 10(5): e0124660.

Nugnes F., Gebiola M., Gualtieri L., Russo E., Sasso R., BERNARDo U., 2016 - When exotic biocontrol agents travel without passport: first record of Quadrastichus mendeli, parasitoid of the blue-gum chalcid Leptocybe invasa, in Italy. - Bull. Insectology, 69: 85-91.

NYEKO P., 2011 - Advances in research and management of tree pests and diseases: experiences from FABI. In: Sawlog production grant scheme, SPGS, pp. 16.

Protasov A., La Salle J., Blumberg D., Brand D., Saphir N., Assael F., Fisher N., Mendel Z., 2007a -
Biology, revised taxonomy and impact on host plants of Ophelimus maskelli, an invasive gall inducer on Eucalyptus spp. in the Mediterranean area. - Phytoparasitica, 35: 50-76.

Protasov A., Blumberg D., Brand D., La Salle J., MENDEL Z., 2007B - Biological control of the eucalyptus gall wasp Ophelimus maskelli (Ashmead): taxonomy and biology of the parasitoid Closterocerus chamaeleon (Girault), with information on its establishment in Israel. - Biol. Control, 42: 196-206.

Protasov A., Doganlar M., La Salle J., Mendel Z., 2008 - Occurrence of two local Megastigmus species parasitic on the Eucalyptus gall wasp Leptocybe invasa in Israel and Turkey. - Phytoparasitica, 36: 449-459.

RAMAN, A. Withers, T.M., 2003 - Oviposition by introduced Ophelimus eucalyptì (Hymenoptera: Eulophidae) and morphogenesis of female-induced galls on Eucalyptus saligna (Myrtaceae) in New Zealand. - B. Entomol. Res., 93: 55-63.

Rizzo M.C., Lo Verde G., Rizzo R., Caleca V., 2015 Risk assessment of non-target effects of Closterocerus chamaeleon (Girault) parasitoid of the eucalypt gall maker Ophelimus maskelli (Ashmead) (Hymenoptera, Eulophidae). - Phytoparasitica, 43: 407-415.

SANGTONGPRAOW B., CHARERnsom K., 2013 - Evaluation of parasitism capacity of Megastigmus thitipornae Dogañlar \& Hassan (Hymenoptera: Torymidae), the local parasitoid of Eucalyptus gall wasp, Leptocybe invasa Fisher \& La Salle (Hymenoptera: Eulophidae). Kasetsart J. (Nat. Sci.), 47: 191-204.

Sasso R., Laudonia S., Viggiani G., 2008 - Dati preliminari per il controllo biologico di Ophelimus maskelli (Ashmead) (Hymenoptera: Eulophidae) in Campania a seguito dell 'introduzione del suo antagonista Closterocerus chamaeleon (Girault) (Hymenoptera: Eulophidae). - Boll. Lab. Ent. Agr. Filippo Silvestri, 62: 51-55.

Soliman E.P., Wilcken C.F., Pereira J.M., Dias T.K.R., Zaché B., Dal Pogetto M.H.F.A., Barbosa L.R., 2012 - Biology of Thaumastocoris peregrinus in different Eucalyptus species and hybrids. - Phytoparasitica, 40: 223-230.

Sopow S., George S., 2012 - Bronze bug, Thaumastocoris peregrinus: a new Eucalyptus pest in New Zealand. Surveillance (Wellington), 39: 43-46. http://www. biosecurity.govt.nz/pub lications/surveillance/index.htm

Streito J. C., Matoce A., Legros V., Genson G., Pierre É., Pluot-Sigwalt D., 2016 - Présence sur l'île de la Réunion de l'espèce invasive Thaumastocoris peregrinus Carpintero \& Dellapé, 2006 (Hemiptera, Heteroptera, Thaumastocoridae). - Bull. Soc. Entomol. Fr., 121: 65-72.

VAN DER Heyden T., 2017 - The first record of Thaumastocoris peregrinus Carpintero \& Dellapé, 2006 (Hemiptera: Heteroptera: Thaumastocoridae) for Albania. - R. Gad. Entomol., 8: 133-135.

VAstrad A.S., Kumari N.K., Goud K., Viraktamath S., 2010 - Monitoring Eucalyptus gall wasp, Leptocybe invasa Fisher and La Salle (Hymenoptera: Eulophidae) using yellow sticky trap in eucalyptus plantation. Karnataka J. Agr. Sci., 23: 215-216.

VigGiani G., NicotinA M., 2001 - L'Eulofide galligeno fogliare degli eucalipti Ophelimus eucalypti (Gahan) (Hymenoptera:Eulophidae) in Campania. - Boll. Zool. Agr. Bach., Ser. II 33: 79-82.

Viggiani G., Laudonia S., Bernardo U., 2001 Aumentano gli insetti dannosi agli eucalipti. - L'Informatore Agrario, 58 (12): 86-87. 
Viggiani G., Laudonia S., SASso R., 2008 - Gli stadi giovanili del parassitoide Closterocerus chamaeleon (Girault) (Hymenoptera: Eulophidae) e il loro sviluppo in rapporto all'eulofide galligeno Ophelimus maskelli (Ashmead). - Boll. Lab. Ent. Agr. Filippo Sivestri, 62: 71-77.

Vivas, L., CRESPO, J. \& JACINTO, V., 2015 - Primer registro de la especie invasora Thaumastocoris peregrinus Carpintero \& Dellapé, 2006 en España y nuevos datos para Portugal (Hemiptera: Thaumastocoridae). - BV Publ. Cient., 4(48): 30-35.

Wilcken C.F., Soliman E.P., Nogueira De SÁ L.A.,
Barbosa L.R., Dias T.K.R., Ferreira-Filho P.J., OliveIR R.J.R., 2010 - Bronze bug Thaumastocoris peregrinus Carpintero and Dellapé (Hemiptera: Thaumastocoridae) on Eucalyptus in Brazil and its distribution - J. Plant Prot. Res., 50: 201-205

Zanuncio A.J.V., Pastori P.L., Kirkendall L.R., LinoNeto J., Serrão J.E., Zanuncio J.C., $2010-$ Megaplatypus mutates (Chapuis) (Coleoptera: Curculionidae: Platypodinae) attacks hybrid Eucalyptus (L.) Héritier de Brutelle clones in southern Espírito Santo, Brazil. - Coleopt. Bull., 64: 81-83. 
80 - Blank Page 